Vovkanych, L., Boretsky, Yu., Sokolovsky, V., Berhtraum, D., \& Kras, S. (2021). Validation of the Software-Hardware Complex "Rytm” for Measurement of the RR Intervals and Heart Rate Variability Analysis During Exercise and Recovery Period. Teoriâ ta Metodika Fizičnogo Vihovannâ, 21(1), 61-68. https://doi.org/10.17309/tmfv.2021.1.08

ISSN 1993-7989 (print). ISSN 1993-7997 (online)

\title{
VALIDATION OF THE SOFTWARE-HARDWARE COMPLEX “RYTM" FOR MEASUREMENT OF THE RR INTERVALS AND HEART RATE VARIABILITY ANALYSIS DURING EXERCISE AND RECOVERY PERIOD
}

\author{
Lyubomyr Vovkanych ${ }^{1 \mathrm{ABCD}}$, Yuriy Boretsky ${ }^{1 \mathrm{ADE}}$, Viktor Sokolovsky ${ }^{1 \mathrm{ACD}}$, \\ Dzvenyslava Berhtraum ${ }^{1 \mathrm{BD}}$, Stanislav Kras ${ }^{1 \mathrm{BD}}$ \\ ${ }^{1}$ Lviv State University of Physical Culture named after Ivan Boberskyj \\ Authors' Contribution: A - Study design; B - Data collection; C - Statistical analysis; D - Manuscript Preparation; E - Funds Collection
}

Corresponding Author: Lyubomyr, Vovkanych, E-mail: lsvovkanych@gmail.com

Accepted for Publication: March 20, 2021

Published: March 25, 2021

DOI: 10.17309/tmfv.2021.1.08

\begin{abstract}
The study purpose was estimation of the accuracy of RR time series measurements by SHC "Rytm" and validity of derived heart rate variability (HRV) indexes under physical loads and recovery period.

Materials and methods. The participants were 20 healthy male adults aged $19.7 \pm 0.23$ years. Data was recorded simultaneously with CardioLab CE12, Polar RS800, and SHC "Rytm". Test protocol included a 2 minute step test (20 steps per minute, platform height $-40 \mathrm{~cm}$ ) with the next 3 minute recovery period. HRV indexes were calculated by Kubios HRV 2.1.

Results. The RR data bias in the case of physical loads was $-0.06 \mathrm{~ms}$, it increased to $0.09-0.33 \mathrm{~ms}$ during the recovery period. The limits of agreement for RR data ranged from $3.7 \mathrm{~ms}$ to $22.8 \mathrm{~ms}$, depending on the period of measurements and pair of compared devices. It is acceptable for the heart rate and HRV estimation. The intraclass correlation coefficients (0.62-1.00) and Spearman correlation coefficient (0.99) were high enough to suggest very high repeatability of the data. We found no significant difference $(\mathrm{p}>0.05)$ and good correlation $(r=0.94-1.00)$ between the majority of HRV indexes, calculated from data of Polar RS800 and SHC "Rytm" in conditions of physical loads (except for LF/ HF ratio) and in the recovery period. The only one index (RMSSD) was different $(p<0.05)$ in case of Polar RS800 and SHC "Rytm" data, obtained in the recovery period. The largest numbers of different HRV indexes have been found during the comparison of CardioLab CE12 and Polar RS800 - RMSSD, pNN50, and SD1. Correlation between HRV indexes $(r=0.81-1.00)$ was very high in all pairs of devices in all periods of measurements.

Conclusions. The SHC "Rytm" appears to be acceptable for RR intervals registration and the HRV analysis during physical loads and recovery period.

Keywords: electrocardiography, Polar RS800, Bland-Altman analysis, intraclass correlation coefficient.
\end{abstract}

\section{Introduction}

To date, the emphasis of many studies is placed on the study of changes in functions of the human organism in stress conditions - diseases, emergency situations, competitive and training activities. These researches aimed at monitoring the indexes of the loads' intensity to track the time course of training adaptation or illness progression in order to avoid pathological changes. To do this, the devices of remote (telemetry) control of the physiological functions are used (Dunn et al., 2018). Such devices are in many cases based on the monitoring of heart rate and other parameters of the cardiovascular system, which could be used as indica-

(C) Vovkanych, L., Boretsky, Yu., Sokolovsky, V., Berhtraum, D., Kras, S., 2021. tors of the intensity and adequacy of physical loads, and as the predictors of pathological changes (Dias \& Cunha, 2018; Majumder et al., 2017).

One of the most effective methods to evaluate the physiological changes which occur in the response to physical loads (Dong, 2016) is an analysis of heart rate variability (HRV). Many observations have shown that HRV indexes may serve for monitoring the exercise intensity, level of cardiovascular autonomic adaptations, and provide a powerful tool for diagnosis of early pathological changes (Dong, 2016; Silva et al., 2014; Vovkanych et al., 2014; Hrynkiv et al., 2012; Vovkanych \& Kachmar, 2010). Thus, the remote monitoring of HRV, combined with the evaluation of main indexes of the cardiovascular system, is of great benefit and offers a possibility of greatly improve the level of physical loads and 
adaptation to them. That is why the research team of the Lviv State University of Physical Culture (LSUPhC, Lviv, Ukraine) has elaborated the software-hardware complex "Rytm" (SHC "Rytm"). This complex is designed for the automatic analysis of HRV and some indexes of human hemodynamic according to methods elaborated by Mukalov I.O. (Drozd et al., 2014). To use the newly elaborated device for the correct analysis of HRV, the high accuracy of the RR intervals registration must be confirmed. The accuracy of the registration can be estimated by comparison of the data, obtained from two devices, one of which is considered to be a reference ("golden standard") one. Such studies have been performed for the Garmin 920 XT (Cassirame et al., 2017), PolarS810 (Braga et al., 2016; Barbosa et al., 2014; Nunan et al., 2008), Polar RS800 in various modifications (Hernando et al., 2018; Barbosa et al., 2014; Montaño et al., 2016), Polar V800 (Caminal et al., 2018; Giles et al., 2015; Giles \& Draper, 2018), Equivital EQ02 (Akintola et al., 2016) and Suunto t6 (Weippert et al., 2010) monitors. The same studies have been done for the SHC "Rytm" (Vovkanych et al., 2020). As the reference devices, the medical ECG recorders or holter ambulatory ECG recorders were used. In previous research, the comparisons have been performed in conditions of physiological rest (Gamelin et al., 2008; Giles \& Draper, 2018; Vovkanych et al., 2020), and in the case of exercise performance (Braga et al., 2016; Cassirame et al., 2017; Giles \& Draper, 2018). In most of the studies, researchers compared both RR intervals and HRV indexes, calculated based on RR intervals time series (Gamelin et al., 2008; Giles \& Draper, 2018; Giles et al., 2015). A large number of studies testify the necessity of the investigation of the accuracy of RR data and derived HRV indexes by the newly developed devices. Our previous research (Vovkanych et al., 2020) revealed a good agreement between RR data and most of the HRV indexes, based on data of SHC "Rytm" and both the medical electrocardiographic system and Polar RS800, in the condition of physiological rest.

The presented paper aims at assessing the accuracy of RR time series measurements by SHC "Rytm" and validity of derived from them HRV indexes in conditions of physical loads and recovery period.

\section{Materials and methods}

\section{Study participants}

Study participants were twenty healthy male adults (aged $19.7 \pm 0.23$ years, height $179.9 \pm 1.6 \mathrm{~cm}$, weight $73.8 \pm 1.9 \mathrm{~kg}$ ), non-smokers, and none was taking any medication. All subjects provided informed consent to participate in the study. The procedures were accorded to the ethical standards of the relevant national, institutional or other body responsible for human research and experimentation, and the principles of the World Medical Association's Declaration of Helsinki. This study was approved by the Ethical Committee of Lviv State University of Physical Culture named after Ivan Boberskyj.

\section{Study organization}

Data was recorded simultaneously with an ECG recorder (CardioLab CE12, XAI-Medica, Kharkiv, Ukraine), Polar RS800 (Polar Electro Oÿ, Kempele, Finland), and SHC "Rytm" (LSUPhC, Lviv, Ukraine). Polar RS800 was used as the "golden standard" device for RR intervals measurements during the physical loads and recovery period. The high level of accuracy of this device was previously confirmed in several studies (Hernando et al., 2018; Barbosa et al., 2014; Montaño et al., 2016; Wallén et al., 2011). The Polar H7 (Polar Electro Oÿ, Kempele, Finland) served as a heart rate sensor at SHC "Rytm", data was transmitted by Bluetooth and registered with the "Rytm" software.

The electrode belts of Polar RS800 and SHC "Rytm" sensor were placed just below the chest muscles as described by the manufacturer. We used a 3-electrode system for ECG recording. The electrodes were placed on the chest wall equidistant from the heart. Test protocol included a 2 minutes step test (20 steps per minute, platform height $-40 \mathrm{~cm}$ ) with the next 3 minutes recovery period. Data were recorded continuously during the step-test and the recovery period.

\section{Statistical analysis}

Obtained by SHC "Rytm", CardioLab CE12, and Polar RS800 the RR intervals series were analyzed by Kubios HRV 2.1 (Kuopio, Finland) software for artifacts correction (low level of correction). The corrected data were synchronized and analyzed by MS Excel version 2010 (Microsoft Inc., USA). Standard statistical methods were used to calculate the means and standard deviations. A paired t-test or, when appropriate, a paired Wilcoxon test, was used to detect the presence of systematic difference. The Bland-Altman statistical analysis with calculation of bias and limits of agreement (LoA), along with a determination of intraclass correlation coefficient (ICC) were used for comparison. Statistical analysis was carried out by MS Excel 2010 and OriginPro 9.1 software. Statistical significance was set at $p=0.05$ level for all analyses.

\section{Results}

Data of table 1 reveals that the number of detected RR intervals and the mean values of the RR intervals were the same for all tested devices both under the physical loads and during the recovery period. The results of CardioLab CE12 are not included in analyses in the case of physical loads because of a large number of artifacts, generated by contracted muscles. Most probably, the artifacts could not be effectively removed by device hardware and software means because the CardioLab CE12 was designed for the ECG recording at rest.

As the normality of data distribution was rejected by Kolmogorov-Smirnov approach, the median values and quartiles (Q1 and Q2) were also analyzed. We have found no difference in the median values of RR intervals and a very small (1 ms) difference in quartile values for all devices (Table 1). These findings strongly support the good repeatability of the HSC "Rytm" data as compared to medical devices or well-approved sports devices.

The most common approaches to analyzing the repeatability of data obtained by different devices are plotting of the Bland-Altman diagram, determination of the limits of agreement (LoA), and the calculation of intraclass correlation coefficient (ICC) (Doğan, 2018; Montenij et al., 2016). The Bland-Altman plots for Polar RS800 and SHC "Rytm" are presented in Fig. 1. Data showed at the plots confirm the good agreement among the devices. 
Vovkanych, L., Boretsky, Yu., Sokolovsky, V., Berhtraum, D., \& Kras, S. (2021). Validation of the Software-Hardware Complex"Rytm" for Measurement of the RR Intervals and Heart Rate Variability Analysis During Exercise and Recovery Period

Table 1. Statistical description of the sets of RR intervals recorded by different devices during the physical loads

\begin{tabular}{lccccc}
\hline \multirow{2}{*}{ Index } & \multicolumn{2}{c}{ Step-test performance } & & \multicolumn{2}{c}{ Recovery period } \\
\cline { 2 - 6 } & Polar RS800 & HSC “Rytm” & CardioLab & Polar RS800 & HSC “Rytm" \\
\hline Number of intervals & 4707 & 4707 & 4785 & 4785 & 4785 \\
Mean (ms) & 489.65 & 489.71 & 731.00 & 730.91 & 731.23 \\
SEM (ms) & 0.90 & 0.90 & 3.13 & 3.13 & 3.13 \\
SD (ms) & 61.46 & 61.46 & 216.84 & 216.70 & 216.85 \\
Median (ms) & 484.00 & 484.00 & 704.00 & 704.00 & 704.00 \\
Q1 (ms) & 484.00 & 484.00 & 557.00 & 557.00 & 558.00 \\
Q3 (ms) & 441.00 & 441.00 & 876.00 & 876.00 & 877.00 \\
\hline
\end{tabular}

Note: M - arithmetical mean; SEM - standard error of the mean; SD - standard deviation, Q1 - 1st quartile; Q3 - 3rd quartile.

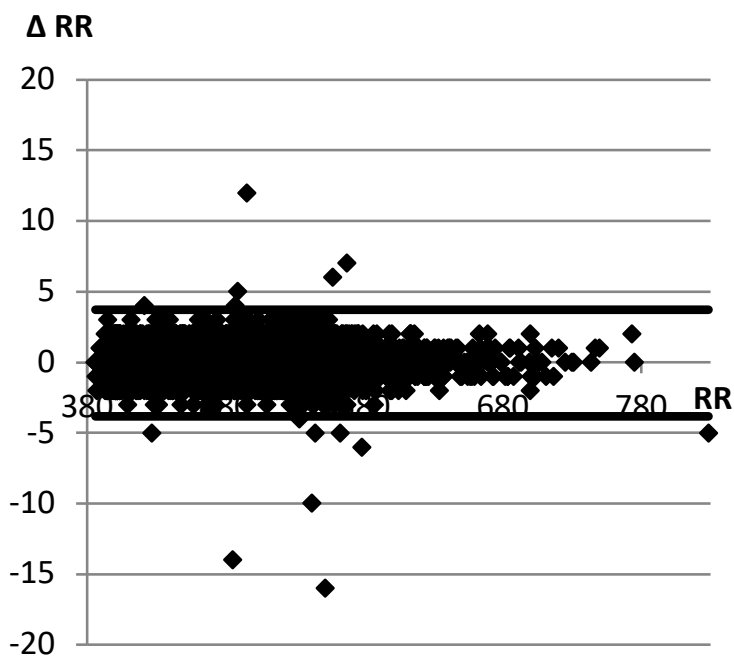

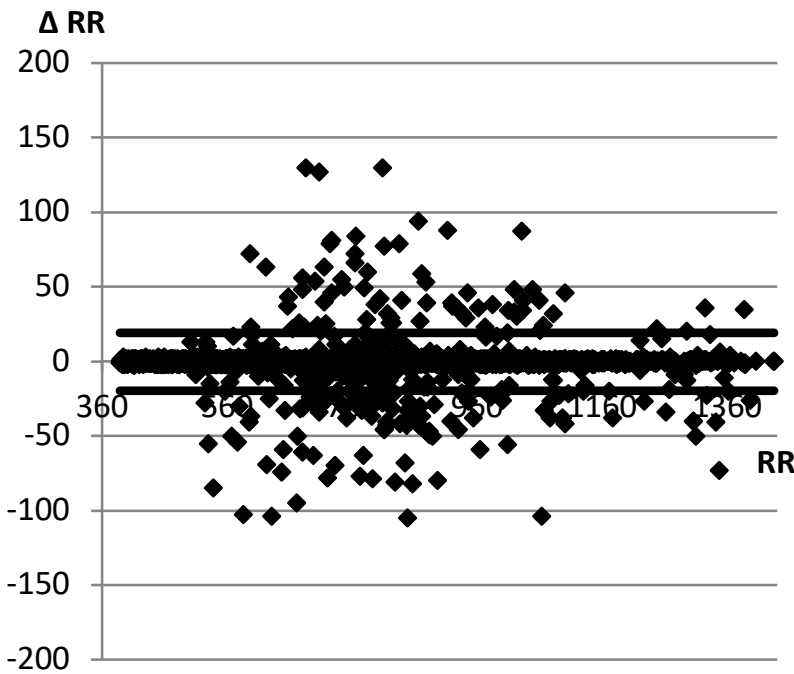

Fig. 1. Bland-Altman plot of RR intervals comparison between Polar RS800 and SHC "Rytm" during the step-test (a) and during the recovery period (b). Limits of agreement are indicated by horizontal lines

Table 2. Analysis of the repeatability in RR time series measured by different devices during the step-test $(n=4707)$ or recovery period after the test $(n=4785)$

\begin{tabular}{|c|c|c|c|c|}
\hline \multirow{3}{*}{ Index } & \multicolumn{4}{|c|}{ Pairs of compared devices } \\
\hline & \multirow{2}{*}{$\begin{array}{c}\text { Step-test } \\
\begin{array}{c}\text { Polar RS800 - HSC } \\
\text { "Rytm" }\end{array}\end{array}$} & \multicolumn{3}{|c|}{ Recovery period } \\
\hline & & $\begin{array}{c}\text { CardioLab - Polar } \\
\text { RS800 }\end{array}$ & $\begin{array}{c}\text { CardioLab - HSC } \\
\text { "Rytm" }\end{array}$ & $\begin{array}{c}\text { Polar RS800 -HSC } \\
\text { "Rytm" }\end{array}$ \\
\hline Mean $\Delta \mathrm{RR}(\mathrm{ms})$ & -0.06 & 0.09 & -0.24 & -0.33 \\
\hline SEM $\Delta \mathrm{RR}(\mathrm{ms})$ & 0.03 & 0.17 & 0.12 & 0.14 \\
\hline LoA (ms) & $-3.83-3.72$ & $-22.60-22.79$ & $-16.18-15.71$ & $-19.74-19.09$ \\
\hline ICC & 1.000 & 0.620 & 0.621 & 0.620 \\
\hline $\mathrm{r}$ & 0.999 & 0.998 & 0.999 & 0.999 \\
\hline
\end{tabular}

Note: Mean $\triangle \mathrm{RR}$ - bias in the duration of the RR interval recorded by two different devices; SEM - standard error of the mean; LoA - limits of agreement; ICC - intraclass correlation coefficient; $r$ - Spearman correlation coefficient

The RR data bias in the case of physical loads was very low $(-0.06 \mathrm{~ms})$, while during the recovery period is increased to $0.09-0.33 \mathrm{~ms}$ (Table 2). As the bias in all cases was less than $1 \mathrm{~ms}$ it could be considered acceptable for the heart rate and HRV estimation. Calculated LoA ranged from $3.7 \mathrm{~ms}$ to $22.8 \mathrm{~ms}$, depending on the period of measurements and pair of compared devices. The LoA tended to be larger for the measurements, performed during the recovery period.
The possible explanation for this is the higher level of the variability of RR intervals and higher duration of RR intervals during recovery, which causes the proportional increase in both bias and LoA.

We determine the intraclass correlation coefficients (ICC) according to the Weir model 3.1 (Koo \& Li, 2016). Both values of ICC (0.62-1.00) and Spearman correlation coefficient (0.99) were high enough to suggest very high re- 
Table 3. Comparison of heart rate variability indexes $(M \pm S E M)$, derived from the $R R$ data from different devices during the step-test

\begin{tabular}{|c|c|c|c|c|c|c|}
\hline \multirow{2}{*}{ HRV index } & \multicolumn{2}{|c|}{ Recording device } & \multicolumn{4}{|c|}{ Polar RS800 - HSC “Rytm” } \\
\hline & Polar RS800 & HSC "Rytm" & $\mathbf{r}$ & $\mathbf{p}$ & bias & LoA \\
\hline Mean RR (ms) & $494.61 \pm 10.73$ & $495.91 \pm 10.81$ & 1.00 & 0.15 & -0.06 & $0.03--0.14$ \\
\hline Mean HR (1/min) & $123.15 \pm 2.73$ & $122.85 \pm 2.75$ & 1.00 & 0.15 & 0.30 & $2.04--1.44$ \\
\hline STD RR (ms) & $37.68 \pm 2.97$ & $37.96 \pm 3.03$ & 1.00 & 0.13 & -0.03 & $0.32--0.38$ \\
\hline RMSSD (ms) & $8.78 \pm 1.27$ & $9.08 \pm 1.35$ & 0.98 & 0.25 & 0.002 & $0.58--0.58$ \\
\hline pNN50 (\%) & $0.44 \pm 0.27$ & $0.54 \pm 0.30$ & 0.97 & 0.24 & -0.03 & $0.34--0.39$ \\
\hline RR tri index & $5.69 \pm 0.39$ & $5.47 \pm 0.34$ & 0.94 & 0.12 & 0.22 & $1.41--0.97$ \\
\hline $\operatorname{VLF}\left(\mathrm{ms}^{2}\right)$ & $382.27 \pm 71.43$ & $386.82 \pm 72.62$ & 1.00 & 0.25 & 0.24 & $3.50--3.02$ \\
\hline $\mathrm{LF}\left(\mathrm{ms}^{2}\right)$ & $39.82 \pm 12.76$ & $39.80 \pm 12.74$ & 1.00 & 0.98 & 0.04 & $1.26--1.17$ \\
\hline $\mathrm{HF}\left(\mathrm{ms}^{2}\right)$ & $24.33 \pm 11.41$ & $24.23 \pm 11.20$ & 1.00 & 0.85 & -0.34 & $2.45--3.14$ \\
\hline VLF (\%) & $79.73 \pm 5.05$ & $79.88 \pm 5.00$ & 1.00 & 0.62 & 0.13 & $1.01--0.76$ \\
\hline LF (\%) & $13.81 \pm 3.73$ & $13.71 \pm 3.72$ & 1.00 & 0.48 & 0.004 & $0.27--0.28$ \\
\hline $\mathrm{HF}(\%)$ & $6.42 \pm 1.99$ & $6.37 \pm 1.93$ & 1.00 & 0.76 & -0.11 & $0.61--0.82$ \\
\hline LF/HF ratio & $3.69 \pm 0.61$ & $3.48 \pm 0.57$ & 0.99 & 0.05 & 0.21 & $1.10--0.67$ \\
\hline SD1 (ms) & $6.25 \pm 0.90$ & $6.47 \pm 0.96$ & 0.98 & 0.24 & 0.001 & $0.41--0.41$ \\
\hline SD2 (ms) & $51.99 \pm 4.21$ & $52.33 \pm 4.29$ & 1.00 & 0.16 & 0.003 & $0.17--0.18$ \\
\hline
\end{tabular}

Note: LoA - limits of agreement; HR - heart rate; STD RR - standard deviation of RR intervals; RMSSD - square root of the mean squared differences between successive RR intervals; pNN50 - percentage of successive intervals with a difference greater than 50 ms compared to the previous interval; RR tri index - the integral of the RR interval histogram divided by the height of the histogram; VLF, LF and HF - absolute (ms2) or relative (\%) powers from very low frequency, low frequency and high frequency bands respectively; LF/HF - ratio of LF to HF; SD1 and SD2 - from Poincaré plot the standard deviation perpendicular to or along to the line-ofidentity respectively

Table 4. Heart rate variability indexes $(\mathrm{M} \pm \mathrm{SEM})$, derived from the $\mathrm{RR}$ data from different devices during recovery period

\begin{tabular}{lccc}
\hline \multirow{2}{*}{ HRV index } & \multicolumn{3}{c}{ Recording device } \\
\cline { 2 - 4 } & Cardio Lab & Polar RS800 & HSC “Rytm” \\
\hline Mean RR (ms) & $754.46 \pm 32.45$ & $754.23 \pm 32.47$ & $754.29 \pm 32.37$ \\
Mean HR (1/min) & $86.92 \pm 3.54$ & $86.90 \pm 3.55$ & $86.87 \pm 3.55$ \\
STD RR (ms) & $165.61 \pm 12.53$ & $165.17 \pm 12.48$ & $165.12 \pm 12.45$ \\
RMSSD (ms) & $56.77 \pm 4.35$ & $55.56 \pm 4.30$ & $56.20 \pm 4.34$ \\
pNN50 (\%) & $33.08 \pm 3.71$ & $32.27 \pm 3.60$ & $32.70 \pm 3.60$ \\
RR tri index & $22.11 \pm 1.59$ & $21.63 \pm 1.61$ & $20.45 \pm 1.47$ \\
VLF (ms ${ }^{2}$ & $10696 \pm 1798.51$ & $10816 \pm 1852.22$ & $10765 \pm 1835.21$ \\
LF (ms ${ }^{2}$ & $2091.77 \pm 464.70$ & $1902.54 \pm 370.65$ & $2090.19 \pm 465.92$ \\
HF (ms $\left.{ }^{2}\right)$ & $1920.12 \pm 212.90$ & $1840.49 \pm 209.59$ & $1913.42 \pm 211.74$ \\
VLF (\%) & $66.59 \pm 3.46$ & $67.43 \pm 3.53$ & $66.69 \pm 3.47$ \\
LF (\%) & $16.66 \pm 2.82$ & $16.12 \pm 2.75$ & $16.62 \pm 2.82$ \\
HF (\%) & $16.71 \pm 1.68$ & $16.42 \pm 1.73$ & $16.67 \pm 1.68$ \\
LF/HF ratio & $1.27 \pm 0.27$ & $1.26 \pm 0.25$ & $1.28 \pm 0.27$ \\
SD1 (ms) & $40.26 \pm 3.09$ & $39.40 \pm 3.05$ & $39.85 \pm 3.08$ \\
SD2 (ms) & $229.95 \pm 17.51$ & $229.56 \pm 17.46$ & $229.40 \pm 17.41$ \\
\hline
\end{tabular}

Note: legend - as in the table 3

peatability of the data (Koo \& Li, 2016). Nevertheless, some differences in the duration of RR intervals, registered by different devices, may cause deviations in the estimation of HRV indexes. Therefore, the final conclusion should be made based on the calculation and analysis of HRV indexes, derived from the obtained data.

On the next stage of the analysis, we intended to test if the obtained values of bias and LoA for RR data were narrow enough to avoid substantial differences in the HRV indexes, derived from the data. For this purpose, the HRV indexes were calculated by Kubios HRV 2.1 software (Kuopio, Finland) from the RR time series, recorded by different devices, with the next comparative analysis (Tables $3-5$ ). The significance of the difference was determined by paired t-test or paired Wilcoxon test, depending on the Shapiro-Wilk criterion of data distribution normality. 
Vovkanych, L., Boretsky, Yu., Sokolovsky, V., Berhtraum, D., \& Kras, S. (2021). Validation of the Software-Hardware Complex"Rytm" for Measurement of the RR Intervals and Heart Rate Variability Analysis During Exercise and Recovery Period

Table 5. Comparison of heart rate variability indexes $(M \pm S E M)$, derived from the $R R$ data from different devices during recovery period

\begin{tabular}{|c|c|c|c|c|c|c|c|c|c|}
\hline \multirow{2}{*}{ HRV index } & \multicolumn{3}{|c|}{ CardioLab CE12 - Polar RS800 } & \multicolumn{3}{|c|}{ CardioLab CE12 - HSC “Rytm” } & \multicolumn{3}{|c|}{ Polar RS800 - HSC “Rytm” } \\
\hline & $\mathbf{r}$ & $\mathbf{p}$ & bias (LoA) & $\mathbf{r}$ & $\mathbf{p}$ & bias (LoA) & $\mathbf{r}$ & $\mathbf{p}$ & bias $($ LoA) \\
\hline Mean RR (ms) & 1.00 & 0.43 & $0.33(2.80 ;-2.15)$ & 1.00 & 0.55 & $0.23(2.80 ;-2.34)$ & 1.00 & 0.80 & $-0.06(1.89 ;-2.01)$ \\
\hline Mean HR (1/min) & 1.00 & 0.80 & $0.01(0.46 ;-0.45)$ & 1.00 & 0.32 & $0.002(0.18 ;-0.18)$ & 1.00 & 0.18 & $0.03(0.23 ;-0.17)$ \\
\hline STD RR (ms) & 1.00 & 0.10 & $0.24(1.90 ;-1.43)$ & 1.00 & 0.16 & $0.50(3.49 ;-2.49)$ & 1.00 & 0.86 & $0.11(2.40 ;-2.17)$ \\
\hline RMSSD (ms) & 1.00 & 0.01 & $1.21(4.63 ;-2.21)$ & 1.00 & 0.08 & $0.34(2.22 ;-1.53)$ & 1.00 & 0.05 & $-0.64(2.09 ;-3.37)$ \\
\hline pNN50 (\%) & 0.99 & 0.05 & $0.81(4.17 ;-2.56)$ & 1.00 & 0.22 & $0.39(3.04 ;-2.27)$ & 1.00 & 0.21 & $-0.42(2.43 ;-3.27)$ \\
\hline RR tri index & 0.89 & 0.53 & $0.48(7.07 ;-6.11)$ & 0.81 & 0.09 & $1.01(7.11 ;-5.09)$ & 0.93 & 0.07 & $1.18(6.53 ;-4.17)$ \\
\hline $\operatorname{VLF}\left(\mathrm{ms}^{2}\right)$ & 1.00 & 0.32 & $5.73(59.63 ;-48.167)$ & 1.00 & 0.38 & $2.15(77.51 ;-73.20)$ & 1.00 & 0.40 & $14.52(93.05 ;-64.00)$ \\
\hline $\mathrm{LF}\left(\mathrm{ms}^{2}\right)$ & 1.00 & 0.08 & $10.99(122.81 ;-100.82)$ & 1.00 & 0.86 & $-1.42(43.13 ;-45.97)$ & 1.00 & 0.09 & $-17.08(56.25 ;-90.40)$ \\
\hline $\mathrm{HF}\left(\mathrm{ms}^{2}\right)$ & 0.96 & 0.22 & $18.363(167.01 ;-129.78)$ & 0.96 & 0.47 & $7.65(65.24 ;-49.94)$ & 1.00 & 0.26 & $-20.71(30.24 ;-71.65$ \\
\hline VLF (\%) & 0.99 & 0.06 & $-0.51(1.73 ;-2.75)$ & 1.00 & 0.36 & $-0.12(0.74 ;-0.98)$ & 0.99 & 0.07 & $0.42(2.33 ;-1.48)$ \\
\hline LF (\%) & 0.99 & 0.08 & $0.37(2.60 ;-1.86)$ & 1.00 & 0.52 & $0.002(0.50 ;-0.49)$ & 1.00 & 0.08 & $-0.33(1.64 ;-2.30)$ \\
\hline $\mathrm{HF}(\%)$ & 0.99 & 0.19 & $0.13(1.43 ;-1.16)$ & 1.00 & 0.68 & $0.12(0.80 ;-0.57)$ & 0.99 & 0.23 & $-0.25(1.51 ;-2.01)$ \\
\hline LF/HF ratio & 0.96 & 0.87 & $0.06(0.67 ;-0.56)$ & 0.95 & 0.44 & $-0.01(0.07 ;-0.08)$ & 1.00 & 0.81 & $-0.02(0.70 ;-0.74)$ \\
\hline SD1 (ms) & 1.00 & 0.01 & $0.70(2.75 ;-1.34)$ & 1.00 & 0.08 & $0.25(1.28 ;-0.78)$ & 1.00 & 0.06 & $-0.21(0.91 ;-1.33)$ \\
\hline $\mathrm{SD} 2$ (ms) & 1.00 & 0.23 & $0.09(1.85 ;-1.67)$ & 1.00 & 0.22 & $-0.19(1.51 ;-1.88)$ & 1.00 & 0.66 & $-0.16(1.05 ;-1.39)$ \\
\hline
\end{tabular}

Note: legend - as in the table 3.

Data of Tables 3 confirmed the absence of significant differences between the majority of HRV indexes, calculated from RR intervals data, obtained by Polar RS800 and HSC "Rytm" during the physical loads. The only exception was $\mathrm{LF} / \mathrm{HF}$ ratio, for which a significant difference in values along with a high range of LoA was found.

Results, presented in Table 4 and 5 , revealed the absence of a significant difference between HRV indexes, based on data of CardioLab CE12 and HSC "Rytm". Comparison of Polar RS800 and HSC "Rytm" found only one case of statistically significant difference - the RMSSD value. However, the small bias $(-0.64$ $\mathrm{ms}$ ) and a range of LoA $(2.09--3.37 \mathrm{~ms})$ seemed to be acceptable for the correct estimation of RMSSD (56-57 ms). The largest numbers of different HRV indexes have been found during the comparison of CardioLab CE12 and Polar RS800. Differences were found between RMSSD, pNN50, and SD1. Correlation between HRV indexes was very high in all pairs of devices.

\section{Discussion}

Most studies dealing with the agreement between RR intervals data, obtained by Polar S810 and other devices, have reported the bias of 0.41-2.4 ms (Caminal et al., 2018; Cassirame et al., 2017; Braga et al., 2016). In the present study, the bias in RR intervals is found to be only $-0.06 \mathrm{~ms}$ during the step-test performance and ranges from $0.09 \mathrm{~ms}$ to $-0.33 \mathrm{~ms}$ for different devices in the recovery period. These results suggested the very low level of the systematic error of RR interval measurements by HSC "Rytm". The suggestion is strongly supported by values of LoA, obtained during comparison of HSC "Rytm" with other devices. The lowest LoA values, found in the case of step-test performance (-3.83-3.72 $\mathrm{ms}$ ), are comparable with findings of Porto et al. (2009) $-6.37-2.67 \mathrm{~ms}$. Although the LoA are found to be larger in the recovery period (up to -19.74-19.09 for the pair Polar RS800-HSC "Rytm"), they remain in the range, reported by other authors - -23.40-24.9 ms (Braga et al., 2016). The values of the Spearman correlation coefficient for HSC "Rytm" data and data from other devices is 0.99 and reach the highest levels, mentioned in other studies (0.97-1.00) (Nunan et al., 2008; Caminal et al., 2018). The ICC is also very high (1.000) in the case of Polar RS800 and HSC "Rytm" comparison during step-test. The levels of ICC (0.62) in a recovery period are not as high, as obtained by other researchers ( 0.98 to 0.9994) (Nunan et al., 2008; Hernando et al., 2018). Despite this, they are high enough to support the suggestion of a good data agreement. In summary, these results provided strong evidence of good repeatability of RR intervals data, obtained under the physical loads by SHC "Rytm" and "gold standard" devices - CardioLab CE12 and Polar RS800.

Because the final goal of the time series of RR intervals registration is the analysis of heart rate variability, we have examined the possible difference between the HRV indexes, calculated from the data of HSC "Rytm" and other devices. First of all, it is advisable to mention the RMSSD index, as it is analyzed in many studies (Nunan et al., 2008; Wallén et al., 2011; Caminal et al., 2018). The ranges of LoA for RMSSD, reported in these researches, in most cases do not exceed $2 \mathrm{~ms}$, although values of 26 and $60 \mathrm{~ms}$ are also registered. Our results reveal the $0.58 \mathrm{~ms}$ range of LoA during the step-test, and up to $4.63 \mathrm{~ms}$ range in the recovery period. Although our data show a low level of LoA, a significant difference is found between RMSSD, obtained in the recovery period from Polar RS800 and both HSC "Rytm" and CardioLab CE12. There is no significant difference between RMSSD, derived from the data of CardioLab CE12 and HSC "Rytm". The correlation coefficient is high $(r=1.00)$ in all cases. Thus, we can suppose the good reproducibility of the results of time-domain HRV analysis, based on the data of HSC "Rytm" and medical ECG device.

Past research revealed the LoA up to $22.6 \mathrm{~ms}^{2}$ for VLF, $68.0 \mathrm{~ms}^{2}$ for LF, and $47.0 \mathrm{~ms}^{2}$ for HF indexes of frequencydomain HRV analysis based on Polar S810 data ECG data (Vanderlei et al., 2008; Wallén et al., 2011; Weippert et al., 2010). Despite the larger ranges of the LoA, obtained in our study during the rest period, we show an absence of significant difference and very high correlation between the VLF, 
LF, and HF indexes, based on the data of HSC "Rytm" and other devices. In the case of physical loads, our data is close to the ranges of 5-7 $\mathrm{ms}^{2}$, reported by other authors (Nunan et al., 2008; Giles \& Draper, 2015). In summary, this finding may indicate the high accuracy of the reproduction of the frequency-domain HRV indexes, based on HSC "Rytm" data.

There are very few studies on the differences in the indexes of nonlinear HRV analysis (SD1 and SD2), derived from the data of Polar S810 and other devices (Gamelin et al., 2006, 2008; Cassirame et al., 2017; Giles et al., 2015). The reported LoA ranged from -0.2-0.24 ms to -0.85-1.55 ms. Our research shows the LoA less than $0.41 \mathrm{~ms}$ in conditions of physical loads, and up to $1.88 \mathrm{~ms}$ during the recovery period. There is no significant difference in the SD1 and SD2, derived from the data of HSC "Rytm" and other devices. Hence, we can suppose the high reproducibility of the nonlinear HRV analysis, derived from the data of HSC "Rytm" and well-approved devices.

The HSC "Rytm" and other devices show very high correlations ( $\mathrm{r}=0.81-1.00)$ between time-domain, frequencydomain, and nonlinear HRV indexes, similar to levels found in previous research with the Polar S810 (Gamelin et al. 2006, 2008; Nunan et al. 2009; Vanderlei et al. 2008). The high correlation is found both in conditions of physical loads and recovery period.

In summary, our results clearly suggest that in conditions of physical loads performance both the mean values and variability of RR intervals, registered by SHC "Rytm", do not differ significantly from those registered by the ECG systems (CardioLab CE12) and sports device with a high level of accuracy (Polar RS800).

\section{Conclusions}

Obtained data confirm the absence of significant differences between the RR time series, registered during the physical loads by SHC "Rytm" and two well-approved devices - ECG recorder CardioLab CE12 and Polar RS800.

Our research provided strong evidence of a good agreement between the HRV indexes (except for the LF/HF ratio) based on SHC "Rytm" and Polar RS800 data in conditions of step-test performance. No differences are found between HRV indexes derived from SHC "Rytm" and CardioLab CE12 data in the recovery period, although some differences are present in RMSSD, pNN50, and SD1 between CardioLab CE12 and Polar RS800. The SHC "Rytm" appears to be acceptable for RR intervals registration and the HRV analysis in conditions of physical loads.

\section{Acknowledgement}

This research was supported under the research project "Creating a non-invasive complex approach to estimation of the adequacy of physical loads in physical therapy and sport" (state registration number $0118 \mathrm{U} 000809$ ).

The authors want to express their gratitude to Dr. Igor Mukalov for sharing his experience and for friendly advice.

\section{Conflict of interest}

The authors declare that there is no conflict of interest.

\section{References}

Dunn, J., Runge, R., \& Snyder, M. (2018). Wearables and the medical revolution. Personalized Medicine, 15(5), 429-448. https://doi.org/10.2217/pme-2018-0044

Dias, D., \& Cunha, J. P. S. (2018). Wearable Health DevicesVital Sign Monitoring, Systems and Technologies. Sensors, 18(8), 2414. https://doi.org/10.3390/s18082414

Majumder, S., Mondal, T., \& Deen, M. (2017). Wearable Sensors for Remote Health Monitoring. Sensors, 17(12), 130. https://doi.org/10.3390/s17010130

Dong, J.-G. (2016). The role of heart rate variability in sports physiology. Experimental and Therapeutic Medicine, 11(5), 1531-1536. https://doi.org/10.3892/etm.2016.3104

Silva, V. P. D., Oliveira, N. A. D., Silveira, H., Mello, R. G. T., \& Deslandes, A. C. (2014). Heart Rate Variability Indexes as a Marker of Chronic Adaptation in Athletes: A Systematic Review. Annals of Noninvasive Electrocardiology, 20(2), 108-118. https://doi.org/10.1111/anec.12237

Vovkanych, L., Kutseryb, T., Hrynkiv, M., \& Muzyka, F. (2014). Heart rate variability as a criterion for sports selection and assessment of the functional state of athletes (in Ukrainian). Fiziolohichnyi zhurnal, 60(3), 163.

Hrynkiv, M., Vovkanych, L., \& Maievska, S. (2012). The study of individual heart variability of elite sportsmen as the criteria to physical loading adaptation (in Ukrainian). Young Sport Science of Ukraine, 3, 52-58.

Vovkanych, L., \& Kachmar P. (2013). Typologycal features of heart rate variability of young rowers (in Ukrainian). Physical Activity, Health and Sport, 3(13), 60-70.

Drozd, I.P., Gridzhuk, M. Yu., \& Mukalov, I.O. (2014). Determination of individual human radioresistance. Saarbrucken: LAP Lambert Academic Publishing. 197 p.

Cassirame, J., Vanhaesebrouck, R., Chevrolat, S., \& Mourot, L. (2017). Accuracy of the Garmin 920 XT HRM to perform HRV analysis. Australasian Physical \& Engineering Sciences in Medicine, 40(4), 831-839. https://doi.org/10.1007/s13246-017-0593-8

Braga, L. M., Prado, G. F., Umeda, I. I. K., Kawauchi, T. S., Taboada, A. M. F., Azevedo, R. S., Filho, H. G. P., Grupi, C. J., Souza, H. C. C., Moreira, D. A. R., \& Nakagawa, N. K. (2016). Reproducibility for Heart Rate Variability Analysis during 6-Min Walk Test in Patients with Heart Failure and Agreement between Devices. PLOS ONE, 11(12), e0167407. https://doi.org/10.1371/journal.pone.0167407

Barbosa M.P.C.R., Silva, N. T. D., Azevedo, F. M. D., Pastre, C. M., \& Vanderlei, L. C. M. (2014). Comparison of Polar ${ }^{\circledR}$ RS800G $3^{\mathrm{Tm}}$ heart rate monitor with Polar ${ }^{\oplus}$ S810i ${ }^{\mathrm{mm}}$ and electrocardiogram to obtain the series of RR intervals and analysis of heart rate variability at rest. Clinical Physiology and Functional Imaging, 36(2), 112-117. https://doi.org/10.1111/cpf.12203

Nunan, D., Jakovljevic, D. G., Donovan, G., Hodges, L. D., Sandercock, G. R. H., \& Brodie, D. A. (2008). Levels of agreement for RR intervals and short-term heart rate variability obtained from the Polar S810 and an alternative system. European Journal of Applied Physiology, 103(5), 529-537. https://doi.org/10.1007/s00421-008-0742-6 
Vovkanych, L., Boretsky, Yu., Sokolovsky, V., Berhtraum, D., \& Kras, S. (2021). Validation of the Software-Hardware Complex"Rytm" for Measurement of the RR Intervals and Heart Rate Variability Analysis During Exercise and Recovery Period

Porto, L. G. G., \& Jr, L. F. J. (2009). Comparison of TimeDomain Short-Term Heart Interval Variability Analysis Using a Wrist-Worn Heart Rate Monitor and the Conventional Electrocardiogram. Pacing and Clinical Electrophysiology, 32(1), 43-51. https://doi.org/10.1111/j.1540-8159.2009.02175.x

Vanderlei, L., Silva, R., Pastre, C., Azevedo, F., \& Godoy, M. (2008). Comparison of the Polar S810i monitor and the ECG for the analysis of heart rate variability in the time and frequency domains. Brazilian Journal of Medical and Biological Research, 41(10), 854-859. https://doi.org/10.1590/s0100-879x2008005000039

Weippert, M., Kumar, M., Kreuzfeld, S., Arndt, D., Rieger, A., \& Stoll, R. (2010). Comparison of three mobile devices for measuring $\mathrm{R}-\mathrm{R}$ intervals and heart rate variability: Polar S810i, Suunto t6 and an ambulatory ECG system. European Journal of Applied Physiology, 109(4), 779-786. https://doi.org/10.1007/s00421-010-1415-9

Hernando, D., Garatachea, N., Almeida, R., Casajús, J. A., \& Bailón, R. (2018). Validation of Heart Rate Monitor Polar RS800 for Heart Rate Variability Analysis During Exercise. Journal of Strength and Conditioning Research, 32(3), 716725. https://doi.org/10.1519/jsc.0000000000001662

Montaño, A., Brown, F., Credeur, D. P., Williams, M. A., \& Stoner, L. (2016). Telemetry-derived heart rate variability responses to a physical stressor. Clinical Physiology and Functional Imaging, 37(4), 421-427. https://doi.org/10.1111/cpf.12320

Wallén, M. B., Hasson, D., Theorell, T., Canlon, B., \& Osika, W. (2011). Possibilities and limitations of the polar RS800 in measuring heart rate variability at rest. European Journal of Applied Physiology, 112(3), 1153-1165. https://doi.org/10.1007/s00421-011-2079-9

Caminal, P., Sola, F., Gomis, P., Guasch, E., Perera, A., Soriano, N., \& Mont, L. (2018). Validity of the Polar V800 monitor for measuring heart rate variability in mountain running route conditions. European Journal of Applied Physiology, 118(3), 669-677. https://doi.org/10.1007/s00421-018-3808-0

Giles, D., Draper, N., \& Neil, W. (2015). Validity of the Polar V800 heart rate monitor to measure RR intervals at rest. European Journal of Applied Physiology, 116(3), 563-571. https://doi.org/10.1007/s00421-015-3303-9

Giles, D. A., \& Draper, N. (2018). Heart Rate Variability During Exercise. Journal of Strength and Conditioning Research,
32(3), 726-735.

https://doi.org/10.1519/jsc.0000000000001800

Akintola, A. A., van de Pol, V., Bimmel, D., Maan, A. C., \& van Heemst, D. (2016). Comparative Analysis of the Equivital EQ02 Lifemonitor with Holter Ambulatory ECG Device for Continuous Measurement of ECG, Heart Rate, and Heart Rate Variability: A Validation Study for Precision and Accuracy. Frontiers in Physiology, 7, Article 391, 1-14. https://doi.org/10.3389/fphys.2016.00391

Vovkanych, L., Boretsky, Y., Sokolovsky, V., Berhtraum, D., \& Kras, S. (2020). Validity of the software-hardware complex "Rytm" for measuring the RR intervals and heart rate variability at rest. Journal of Physical Education and Sport, 20(3), 1599-1605. https://doi.org/10.7752/jpes.2020.03218

Gamelin, F. X., Berthoin, S., \& Bosquet, L. (2006). Validity of the Polar S810 Heart Rate Monitor to Measure R-R Intervals at Rest. Medicine \& Science in Sports \& Exercise, 38(5), 887-893. https://doi.org/10.1249/01.mss.0000218135.79476.9c

Gamelin, F.-X., Baquet, G., Berthoin, S., \& Bosquet, L. (2008). Validity of the Polar S810 to Measure R-R Intervals in Children. International Journal of Sports Medicine, 29(2), 134-138. https://doi.org/10.1055/s-2007-964995

Kingsley, M., Lewis, M. J., \& Marson, R. E. (2005). Comparison of Polar $810 \mathrm{~s}$ and an Ambulatory ECG System for RR Interval Measurement During Progressive Exercise. International Journal of Sports Medicine, 26(01/02), 39-44. https://doi.org/10.1055/s-2004-817878

Doğan, N. Ö. (2018). Bland-Altman analysis: A paradigm to understand correlation and agreement. Turkish Journal of Emergency Medicine, 18(4), 139-141. https://doi.org/10.1016/j.tjem.2018.09.001

Montenij, L. J., Buhre, W. F., Jansen, J. R., Kruitwagen, C. L., \& de Waal, E. E. (2016). Methodology of method comparison studies evaluating the validity of cardiac output monitors: a stepwise approach and checklist. British Journal of Anaesthesia, 116(6), 750-758. https://doi.org/10.1093/bja/aew094

Koo, T. K., \& Li, M. Y. (2016). A Guideline of Selecting and Reporting Intraclass Correlation Coefficients for Reliability Research. Journal of Chiropractic Medicine, 15(2), 155-163. https://doi.org/10.1016/j.jcm.2016.02.012 


\title{
АПРОБАЦІЯ ВИКОРИСТАННЯ ПРОГРАМНО-АПАРАТНОГО КОМПЛЕКСУ «РИТМ» ДЛЯ ВИМІРЮВАННЯ КАРДІОІНТЕРВАЛІВ ТА АНАЛІЗУ ВАРІАБЕЛЬНОСТІ СЕРЦЕВОГО РИТМУ В УМОВАХ ФІЗИЧНИХ ВПРАВ ТА ВІДНОВЛЕННЯ
}

\author{
Любомир Вовканич ${ }^{1 \mathrm{ABCD}}$, Юрій Борецький ${ }^{1 \mathrm{ADE}}$, Віктор Соколовський $^{1 \mathrm{ACD}}$, \\ Дзвенислава Бергтраум ${ }^{1 B D}$, Станіслав Крась ${ }^{1 B D}$ \\ ${ }^{1}$ Львівський державний університет фізичної культури імені Івана Боберського \\ Авторський вклад: А - дизайн дослідження; В - збір даних; C - статаналіз; D - підготовка рукопису; Е - збір коштів \\ Реферат. Стаття: 8 с., 1 рис., 5 табл., 30 джерел.
}

Метою дослідження була оцінка точності вимірювань часових рядів кардіоінтервалів та отриманих на їхній основі показників варіабельності серцевого ритму (ВСР) за допомогою програмно-апаратного комплексу (ПАК) «Ритм» в умовах фізичних навантажень та періоду відновлення.

Матеріали і методи. Учасниками досліджень були 20 осіб віком 19,7 \pm 0,23 років, чоловічої статі, без виявлених патологій. Дані реєстрували одночасно з використанням CardioLab CE12, Polar RS800 та ПАК «Ритм». Досліджувані виконували 2-хвилинний степ-тест (20 кроків на хвилину, висота сходинки - 40 см) з наступними 3-хвилинним періодом відпочинку. Показники ВСР розраховували з використанням Kubios HRV 2.1.

Результати. Середнє відхилення тривалості кардіоінтервалу в умовах фізичних навантажень становило -0,06 мс, у період відновлення ця величина зростала до 0,09-0,33 мс. Межі довірчих інтервалів коливались від 3,7 мс до 22,8 мс, залежно від періоду вимірювань та пари порівнюваних пристроїв. Ці величини можна вважати прийнятними для коректного оцінювання частоти серцевих скорочень та ВСР. Значення внутрішньокласових коефіцієнтів кореляції (0,62-
$1,00)$ та коефіцієнтів кореляції Спірмена $(0,99)$ були досить високими, щоб припустити дуже високу відтворюваність даних. Нами не виявлено вірогідної різниці $(\mathrm{p}>0,05)$ та показана тісна кореляція $(\mathrm{r}=0,94-1,00)$ між більшістю індексів BCP, розрахованих за даними Polar RS800 та ПАК «Ритм», як в умовах фізичних навантажень (окрім LF/HF), так і в період відновлення. Порівняння даних Polar RS800 та ПАК «Ритм», отриманих у період відновлення, вказує на наявність відмінності $(\mathrm{p}<0,05)$ лише для одного показника (RMSSD). Найбільша кількість відмінностей у показниках BCP виявлена під час порівняння CardioLab CE12 та Polar RS800 - RMSSD, pNN50 та SD1. Виявлена тісна кореляція між показниками ВСР (r =0,81-1,00) для всіх пар приладів та у всі періоди вимірювань.

Висновки. ПАК «Ритм» характеризується прийнятним рівнем точності вимірювання кардіоінтервалів та аналізу ВСР в умовах фізичних навантажень та в період відновлення.

Ключові слова: електрокардіографія, Polar RS800, аналіз Бленда-Альтмана, коефіцієнт кореляції внутрішньокласового зв'язку.

\section{Information about the authors:}

Vovkanych L.S.: lsvovkanych@gmail.com, anatom@ldufk.edu.ua; https://orcid.org/0000-0002-6642-6368; Lviv State University of Physical Culture named after Ivan Boberskyj, Department of Anatomy and Physiology, Kostiushka St, 11, Lviv, 79007, Ukraine.

Boretsky Y.R.: biolog@ldufk.edu.ua; https://orcid.org/0000-0001-7892-8915; Lviv State University of Physical Culture named after Ivan Boberskyj, Department of Anatomy and Physiology, Kostiushka St, 11, Lviv, 79007, Ukraine.

Sokolovsky V. M.: admin@ldufk.ua; https://orcid.org/0000-0003-0704-2265; Lviv State University of Physical Culture named after Ivan Boberskyj, Department of Anatomy and Physiology, Kostiushka St, 11, Lviv, 79007, Ukraine.

Berhtraum D.I.: bergtraumdzvenyslava@gmail.com; https://orcid.org/0000-0003-2024-1744; Lviv State University of Physical Culture named after Ivan Boberskyj, Department of Anatomy and Physiology, Kostiushka St, 11, Lviv, 79007, Ukraine.

Kras S.I.: marykras@ukr.net; https://orcid.org/0000-0002-9065-8476; Lviv State University of Physical Culture named after Ivan Boberskyj, Department of Anatomy and Physiology, Kostiushka St, 11, Lviv, 79007, Ukraine.

Cite this article as: Vovkanych, L., Boretsky, Yu., Sokolovsky, V., Berhtraum, D., \& Kras, S. (2021). Validation of the SoftwareHardware Complex "Rytm" for Measurement of the RR Intervals and Heart Rate Variability Analysis During Exercise and Recovery Period. Teoriâ ta Metodika Fizičnogo Vihovannâ, 21(1), 61-68. https://doi.org/10.17309/tmfv.2021.1.08

Received: 02.02.2021. Accepted: 20.03.2021. Published: 25.03.2021

This work is licensed under a Creative Commons Attribution 4.0 International License

(http://creativecommons.org/licenses/by/4.0). 